\title{
Hedgerows and Enclosures in Rural Areas: Traditional vs. Modern Land Use in Mediterranean Mountains
}

\author{
Fernando Allende Álvarez *, Gillian Gómez-Mediavilla, Nieves López-Estébanez (D), Pedro Molina Holgado and \\ Judith Ares Barajas
}

check for updates

Citation: Álvarez, F.A.;

Gómez-Mediavilla, G.;

López-Estébanez, N.; Holgado, P.M.;

Barajas, J.A. Hedgerows and

Enclosures in Rural Areas:

Traditional vs. Modern Land Use in Mediterranean Mountains. Land 2021,

10, 57. https://doi.org/10.3390/

land10010057

Received: 26 November 2020

Accepted: 7 January 2021

Published: 10 January 2021

Publisher's Note: MDPI stays neutral with regard to jurisdictional clai$\mathrm{ms}$ in published maps and institutional affiliations.

Copyright: $(\odot 2021$ by the authors. Licensee MDPI, Basel, Switzerland. This article is an open access article distributed under the terms and conditions of the Creative Commons Attribution (CC BY) license (https:// creativecommons.org/licenses/by/ $4.0 /)$.
Department of Geography, Universidad Autónoma de Madrid, 28049 Madrid, Spain; gillian.gomez@uam.es (G.G.-M.); nieves.lopez@uam.es (N.L.-E.); pedro.molina@uam.es (P.M.H.); judith.ares@uam.es (J.A.B.)

* Correspondence: fernando.alllende@uam.es
Abstract: The present paper highlights the importance of hedgerows and enclosures in the mountains of Central Spain. Now, these landscapes have suffered profound variations in terms of agroforestry practices, especially in the Mediterranean mountains where the characteristic multifunctional has largely been lost. The article analyzes land uses changes, dynamics, and their morphological features between the first half of the 20th Century (1956) and the second decade of the present time (2019). The paper was divided into three sections. First, the identification of land uses using orthophotograph and aerial photograph; after that the info was checked with fieldwork. Eleven categories were identified according to the dominant use and land use changes and size of land parcels were taken into consideration. Second, the configuration and the information collected through the type and intensity of change in land uses made it possible to recognise and quantify their distribution and trend between these two dates. Also, the kernel density algorithm available in the Arcgis 10.5 software was used to obtain density and changes in land parcels. Finally, an overview is given of the main role that this agroforestry plays due to the social, ecological, and economic benefits that they provide for allowing sustainable development.

Keywords: hedgerows; Mediterranean mountains; land use changes; rural development; cultural landscape

\section{Introduction}

In the European landscape, field enclosures are associated with terms such as bocage, hedgerow network, etc., and they are most characteristically represented in the Atlantic area where they represent one of the most common landscapes. These landscapes have suffered profound variations in terms of agroforestry practices where the characteristic multifunctional agrosystem (silvoarable agroforestry) has largely been lost. This productive model was characterized by widely spaced trees inter-cropped with annual or perennial crops, which alley cropping, scattered trees and line belts where silvopasture practices were combined. In short, these areas were maintained through a combination of forest or woodland grazing and open forest trees [1]. At present, this terrain has been reoriented towards extensive livestock farming systems that can be adapted to integrated sustainable production $[2,3]$. Despite its characteristics, potential and its relative extension in the south of the European continent, this type of Mediterranean field enclosure goes unnoticed in the many classifications of available of Wooded grasslands [4,5]. Within this type of landscape are included some of the most interesting agroforestry areas in the continental Mediterranean mountains: field enclosures. These spaces are defined by the existence of linear elements such as shrubs, trees or dry stone walls, whose main function is to establish a boundary [6,7]. Agroforestry landscapes are a major factor in the conservation of biodiversity [8-10] and in turn, they possess outstanding aesthetic and cultural value [11]. 
Nowadays, hedgerows are going through a progressive revaluation of their agroecological and cultural values [11-14]. Their multifunctional productivity (wood, firewood, charcoal) has generated a silvo-structural diversity of great natural heritage interest (pollarded trees, coppiced woodlands, dense hawthorn hedges, woodlands and hedgerows) [15]. In cases where enclosures still maintain their functionality, they retain an economic value that is difficult to evaluate and they provide ecological services to agro-livestock systems that contribute to soil fertility, protection and productivity [16-19]. In addition, hedgerows improve landscape heterogeneity and increase biotic connectivity $[6,20]$, and their presence improves the structure, composition and functionality of rural landscapes over time [17].

However, Mediterranean enclosed fields have undergone multiple changes due to the new social and territorial situation. These changes are related to their use and exploitation but also, to the structure of the land parcels. The transformation of the rural environment (rural exodus, decline in agricultural activities, etc.), particularly since the 1950s, favoured the widespread abandonment of cultivated terrains. In particular, cereal crops almost completely disappeared from the continental Mediterranean mountains, converting to pastures for grazing. The most representative traditional crops have suffered the same fate, flax fields and local self-sufficiency market garden crops. The loss of pastures, both hay meadows and those for livestock grazing, is also noteworthy. Nevertheless, the abandonment of fields has not occurred uniformly but has concentrated the most marginal and driest terrain, and those that are less accessible [21]. In addition to the changes in use, this agrosystem has undergone modifications in relation to the structure of the land parcels, which is considered to reflect an inheritance of wealth [22,23], both in terms of landscape and biology [24]. As such, morphological analysis and multitemporal studies enable microstructures to be identified and classified [25], and the relevance of structural landscape calculations to be recognized [26].

The paper deals as a fundamental objective a diachronic analysis of enclosed areas in three domains of the piedmont of the Sierra de Guadarrama. This work was made for two reference dates (1956 and 2019); for each date were identified and quantified different types of land uses and the changes and dynamics of them were classified using GIS methods. As such, the results of this work were structured into two sections: the changes in land use and the evolution and transformation of the land parcels in terms of configuration and density. This approach means an advance in the knowledge of the enclosed fields of the continental Mediterranean mountains especially as it concerns land parcel density and the identification, development, and analysis of traditional land uses in the last 70 years.

\section{Materials and Methods}

\subsection{Study Area}

This study was carried out in the Central Spanish mountainous System, focusing on three study areas located in the southern foothills of these mountains situated in the centre of the region of Madrid (Figure 1). This is a Germanic-type topography, where arrangements are originated by Hercynian tectonics (NE-SW). The mountainous ridges present a topography with raised blocks of a Hercynian orogeny (horst) in high-lying areas and with valleys situated on sunken blocks (graben). Granite and metamorphic lithologies predominate, along with the materials derived from their decomposition. It is a sector with a continental Mediterranean climate, with average annual temperatures of $6.9^{\circ} \mathrm{C}$ (Puerto de Navacerrada, 1981-2010 series) [27], rainfall concentrated in the equinoxes, a dry season during the summer months, and average annual precipitation of $1223 \mathrm{~mm}$ (Puerto de Navacerrada, 1981-2010 series) [27]. 


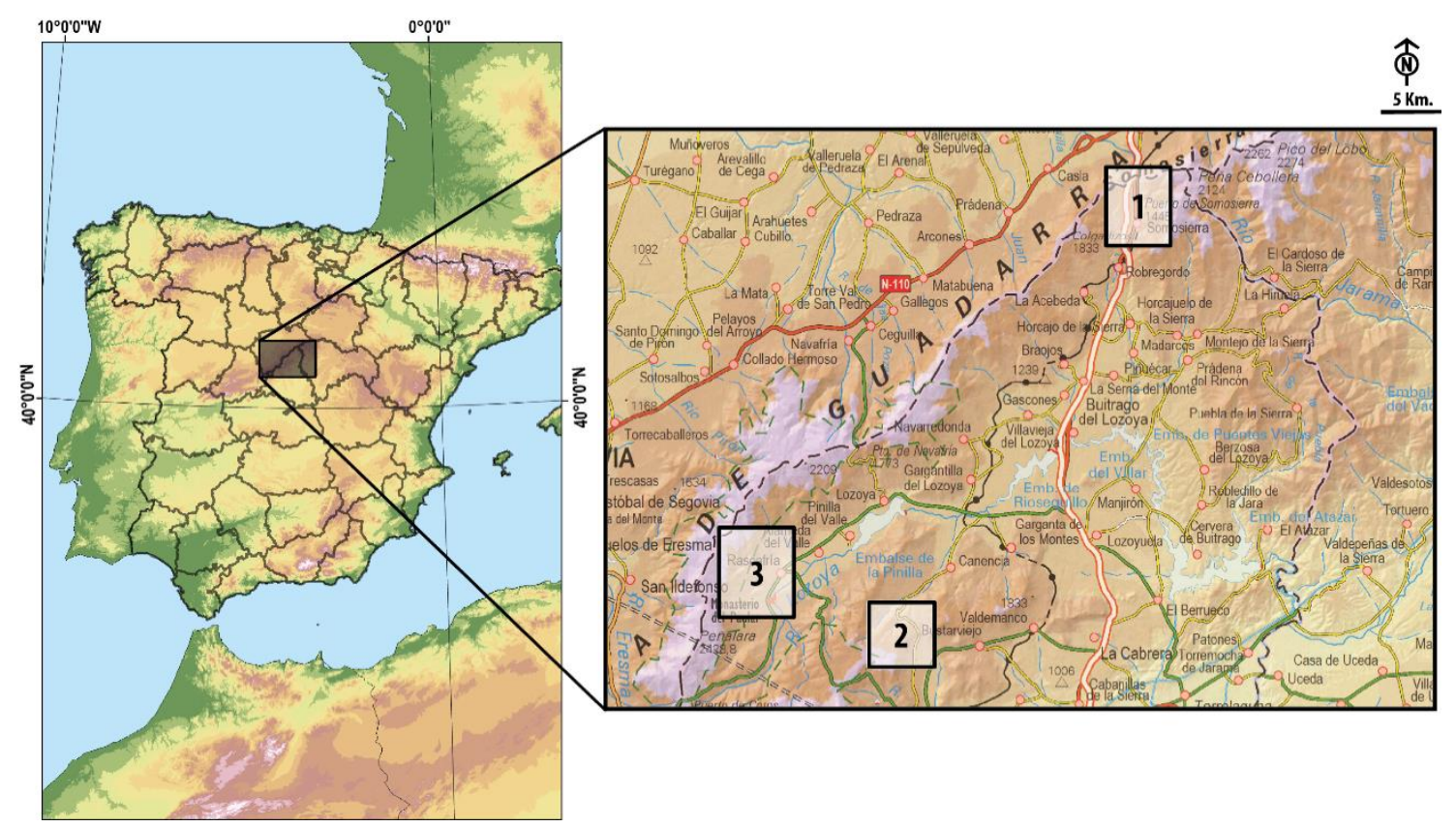

Figure 1. Study area (1. Somosierra; 2. Bustarviejo-Arroyo del Valle; 3. Rascafría). Map base source: Spain MDE from USGS Shuttle Radar Topography, 2004 [28]. Topographic information from the National Geographic Institute 1:200,000 [29].

In this sector of the piedmont and conditioned by the organization of the physical environment, some of the most unique enclosed spaces of the Mediterranean interior mountains can be found. Enclosures made of dry stone, trees, scrubs or the mosaics of all of these are the main features common to Somosierra, Arroyo del Valle (Bustarviejo) and Rascafría. These three cases selected are heterogeneous in terms of their morphology, functionality and location (Table 1). They are characterized by fragmented and dense parcels of land in the most productive and humid sectors of the valley floor, which was multifunctional until the middle of the 20th century, and that occupied a large part of the fertile land in the valleys, rich in water resources, and of the slopes in the immediate vicinity.

Table 1. Physiographic characteristics of the case studies.

\section{Cases}

Case 1. Somosierra

Case 2. Bustarviejo (Arroyo del Valle)

\section{Physiographic Characteristics}

Linearity associated with plate tectonics.

Small, compartmentalized and well-defined valley bottom.

Dispersed land parcels that occupy both slopes of the mountain pass, better developed on the southern slope, higher, with less steeper slopes and with a more favourable climate.

Massif slopes with lax and sometimes poorly defined enclosure boundaries. Middle-lower slopes enclosed by solifluid fronts with natural vegetation.

Alteration alveolar on granite materials with subalve moisture and abundant runoff from the slope.

Fertile area concentrated in the central sector of the alveole.

Valley bottom and low slopes occasionally covered by colluvium and alluvial fans Middle slopes with steep slopes.

High density enclosed parcels arranged concentrically.

A rift valley of triangular morphology drained by the Lozoya river (Tagus river basin). Flat, wide and wet valley bottom.

Case 3. Rascafría
Fertile floodplain of the Lozoya River and fluvio-torrential cones in the tributary streams.

Moderate slopes in a succession of structural landings

High-density of land parcels, concentrated in the valley bottom and immediate slopes, which entity and density are progressively lost as the slopes ascend. 


\subsection{Methods}

\subsubsection{Defining Hedgerow and Enclosures}

The enclosed fields in the three aforementioned areas of study were identified and characterized at two different time points (1956 and 2019). For this purpose, the enclosed fields were considered as spaces with a perimeter closure that is in most cases welldefined. Although the use of dry stone walls predominates in the enclosures and those created by shrub hedges or trees were also considered. This incorporates the definition of Baudry et al. [5] regarding this type of landscape "as a linear feature comprising shrubs and / or trees that forms part of a management unit", in which the enclosure essentially constitutes the boundary.

\subsubsection{Photointerpretation, GIS Integration and Land Use Change}

In a first phase, aerial orthophotography from 2019 [30] and ortho-rectified black and white historical photographs from 1956 [31] were used as reference information. In both cases there was a slight mismatch due to the differences in their geometries. This variation has been eliminated by adjusting the polygons defined in 2019 to the 1956 image. Photointerpretation was performed for both dates at a scale of 1:5000, which facilitated the homogenization of contour tracing. The information was digitized in a polygonal format, coding the land uses in a numeric format. To support the photointerpretation process, the Web Map Server of the Rustic Cadastre [32] was used and soil moisture data was retrieved from SENTINEL-2 [33,34]. Once the information had been topologically validated, fieldwork was carried out to corroborate the photointerpretation using linear transects that start in the main settlement and reach the boundaries of the enclosed space. Historical cartographic sources available at the Spanish National Geographic Institute were also used to analyse the traditional arrangement of the enclosed and cultivated ager, and that of unproductive saltus.

Land use was classified into 11 categories (a more detailed description in Table 2), defined according to the dominant use and the dynamics of change between the chosen dates. Grasslands, fruit and vegetable crops, woodland, and scrubland are among the common categories distinguished on both dates. Alternatively, areas dedicated to dryland farming were only evident in 1956, while in 2019 new categories of use emerged in enclosed lands such as woodland, scrubland and grassland, urban land, roads and infrastructures, and enclosed wasteland. The dynamics of use were added to each category, classifying pastures according to their topographic position (valley bottom or slope), their wet or dry nature, as well as the presence of scrub or trees in the pasture areas. Furthermore, enclosed field spaces that were completely abandoned and colonized by trees and/or scrub were assessed.

The climatic peculiarities of the years in which the aerial images were taken were of special interest to identify and characterize the enclosed spaces. The phenology of the vegetation on both dates was proportional to the accumulated moisture and the chromatic features of the grasslands and cultivated areas in the images. In 1956 the images were in black and white (United States Air Force) and they were taken in different months: Somosierra (September), Rascafría (June), and Bustarviejo (May). By contrast, the 2019 colour orthophotography was performed exclusively in the month of May (PNOA, consulted in August 2020). The Navacerrada meteorological station was used to characterize the climatic year, since it was the only one that had comparable data for both dates. Precipitation at the Navacerrada station was lower in both years, than the average from historical records (1349.8 mm): $1071 \mathrm{~mm}$ (1956), and 1153.14 (2019) [27]. The climatic year accumulated a rainfall deficit, especially in spring, with average rainfall between $288 \mathrm{~mm}$ and $203 \mathrm{~mm}$ compared to the average of $362.1 \mathrm{~mm}$. The situation was accentuated in the summer period with the accumulated values of $65.1 \mathrm{~mm}$ and $65.6 \mathrm{~mm}$ recorded, far from the average $127.6 \mathrm{~mm}$. 
Table 2. Land use categories in 1956 and 2019.

\begin{tabular}{|c|c|c|}
\hline Code & Use in 1956 & Use in 2019 \\
\hline 1 & Grassland (Festuca, Poa, Agrostis) & Grassland (Festuca, Poa, Agrostis) \\
\hline 2 & Sloping wet pastures (Nardus, Festuca) & Sloping wet pastures (Nardus, Festuca) \\
\hline 3 & $\begin{array}{c}\text { Valley Floor wet pasture (Arrhenatherum, Agrostis, Poa, } \\
\text { Cynosurus) }\end{array}$ & $\begin{array}{l}\text { Valley bottom wet pasture (Arrhenatherum, Agrostis, } \\
\text { Poa, Cynosurus) }\end{array}$ \\
\hline 4 & Dryland farming (Secale, Triticum) & 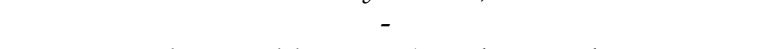 \\
\hline 5 & $\begin{array}{c}\text { Fruit and vegetable crops (Junglans, Malus, Pyrus, } \\
\text { Linum, Brassica, Triticum, Hordeum) }\end{array}$ & $\begin{array}{c}\text { Fruit and vegetable crops (Junglans, Malus, Pyrus, } \\
\text { Hordeum) }\end{array}$ \\
\hline 6 & $\begin{array}{l}\text { Woodland with pasture (Quercus, Fraxinus, Juniperus, } \\
\text { Salix, Agrostis, Poa) }\end{array}$ & $\begin{array}{l}\text { Woodland with pasture (Quercus, Fraxinus, Juniperus, } \\
\text { Salix, Agrostis, Poa) }\end{array}$ \\
\hline 7 & Scrubland with pastures (Genista, Cytisus, Agrostis) & $\begin{array}{c}\text { Scrubland with pastures (Genista, Cytisus, Rosa, Rubus, } \\
\text { Prunus, Agrostis) }\end{array}$ \\
\hline 8 & - & $\begin{array}{l}\text { Woodland, scrubland and grassland (Quercus, } \\
\text { Fraxinus, Genista, Cytisus, Agrostis, Poa) }\end{array}$ \\
\hline 9 & - & Urban land \\
\hline 10 & - & Roads and infrastructures \\
\hline 11 & - & $\begin{array}{c}\text { Enclosed wasteland (Quercus, Fraxinus, Genista, } \\
\text { Cytisus) }\end{array}$ \\
\hline
\end{tabular}

\subsubsection{Kernel Density Estimation (kde)}

The kernel density (kde) algorithm available in the Arcgis 10.5 software was used to obtain density distributions in the enclosed field parcels. This method enables groupings of data to be obtained at defined intervals, which allow hot spot areas of reference to be set $[35,36]$, which helps define the relationships to their closest neighbours $[37,38]$. With this system, better results are obtained than when using linear regression [39] and a good sample of the probability distributions of the data sets [40] to fit a smoothly tapered surface to each point or polyline [41].

Prior to this process, the polygonal information was converted to linear data, in each case resulting in an area with sufficient line density and with an optimal spatial distribution. Two calculations were performed for the three cases: one in which differentiated values were obtained for 1956 and 2019; and another one in which the differences between the two values was obtained, and the variation between the two years is reflected in a common mask of 2019. Hectares were used as the reference measurement in the calculations, and $\mathrm{km}^{2}$ as the units for output data (raster format and $0.5 \mathrm{~m}$ resolution). Finally, the density values and those of change were determined at three intervals obtained from the automatic classification (low, medium, and high), as estimated by the calculation algorithm.

\section{Results}

\subsection{Years of Changes in Land Use}

A total of 5412 polygons that corresponded to enclosed fields in 1956 were mapped: 2365 in Somosierra; 1132 in Bustarviejo; and 1915 in Rascafría. At that time, the area occupied by enclosed fields in the sectors studied was 328.93 ha in Somosierra, 458.07 in Bustarviejo and 1390.55 in Rascafría, a total of 2177.55 ha. Almost 70 years later, this agrosystem occupied only 1517.30 ha in the three cases, representing a 53.5\% reduction in Somosierra, a 16.5\% loss in Bustarviejo and 29.4\% less in Rascafría (Figure 2). Among the enclosed fields that have disappeared, a total of 557.21 ha have become part of woody areas covered by coloniser scrubs, the phenomenon of wasteland conquest by plants being common in all three areas: Somosierra 161.18 ha- $91.60 \%$; Bustarviejo 59.49 ha-78.49\%; and Rascafría 336.54 ha- $82.38 \%$. The rest of the areas have disappeared or have been urbanised (91.45 ha), although a significant difference is observed between the nucleus of Somosierra where only $1.81 \%$ of the enclosed fields have become urban, and Bustarviejo or Rascafría with $21.51 \%$ and $17.65 \%$ urbanisation of what were enclosed fields, respectively. In the latter cases, the shorter distance from Rascafría and Bustarviejo to the metropolitan area of Madrid has been fundamental in the transformation towards a landscape with a 
stronger urban component. Finally, in the case of Somosierra alone, a small proportion of the enclosed fields that have disappeared $(11.59$ ha- $6.59 \%)$ have been transformed into roads and other ground infrastructures.
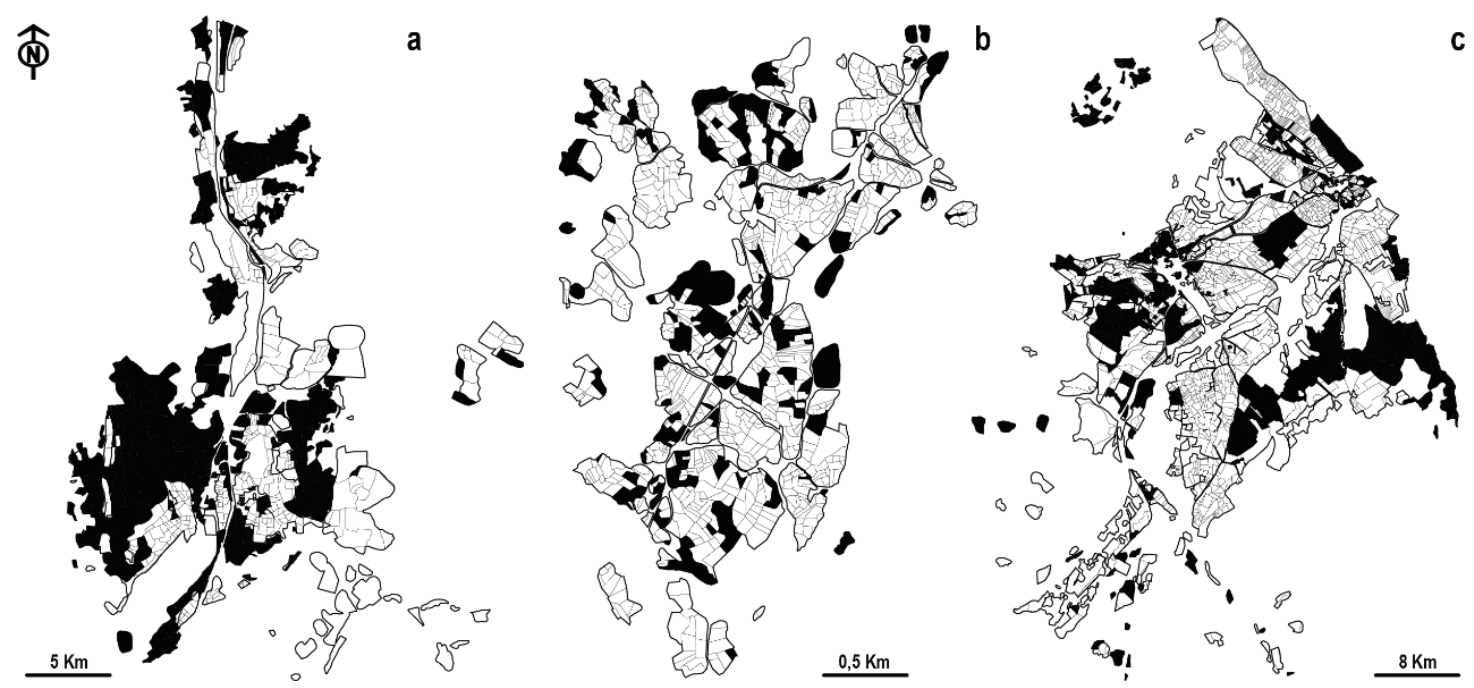

Figure 2. Enclosed fields that have disappeared (in black) between 1956 and 2019 in the three study cases: (a). Somosierra; (b). Arroyo del Valle-Bustarviejo; (c). Rascafría. Own elaboration.

By contrast, a total of 653.71 ha of the enclosed areas have remained stable and without any change in land uses between the two dates analysed: $11.4 \%$ in Somosierra; $15.1 \%$ in Bustarviejo; and 73.6\% in Rascafría. Among the enclosed land in each nucleus with the greatest weight in which the uses remain stable are: sloping pastures in Somosierra, woodland with pastures in Bustarviejo, and valley bottom wet pastures in Rascafria.

In 1956, the landscape of the enclosed fields offered a remarkable variety of uses, identifying up to seven categories: grassland, sloping wet pasture, valley bottom wet pasture, dryland farming, fruit and vegetable crops, woodland with pastures and scrubland with pastures (Figure 3). Although all these categories were recognised in the three cases analysed. However, enclosures dedicated to crop cultivation, especially cereal, were the most prevalent category of land use in all three cases, representing more than 50\% of the total enclosures in Rascafría. In Somosierra, in addition to farming land (38.35\%), sloping wet pastures (38.36\%) stand out. By contrast, the mosaic of uses was more varied in Bustarviejo, and after dryland farming (38.17\%) the presence of sloping wet pastures (19.56\%), woodland with pastures $(13.23 \%)$ and valley bottom wet pasture $(11.09 \%)$ was also notable. Finally, in Rascafría, after farming land (50.81\%), valley bottom wet pasture $(30.03 \%)$ was the next most prevalent land use.

In 2019, 7 land use categories were identified but with two notable differences. In the first place. Dryland farming, the main use of the enclosures of the three study areas 70 years ago, had disappeared completely from all the enclosed fields. In addition, a new category emerged woodland, scrubland, and grassland, which accounted for almost $10 \%$ of the enclosed fields in the case of Somosierra and Bustarviejo.

The differences between each of the nuclei analysed were assessed (Figure 3) and none of the nuclei responded identically to the changes, although there was a common parameter in all three, the disappearance of dryland farming. From this common node, each case underwent different modifications in terms of land use. While Somosierra maintained sloping wet pastures and increased its scrubland with pastures and woodlands, Bustarviejo expanded its woodland with pastures and Rascafría increased both the valley bottom wet pastures and woodland with pastures. Up to 53 types of changes in land use were identified between 1956 and 2019 (Table 3). The changes in land use of enclosed parcels between the two dates that exceed 20 ha were mainly from dryland farming to wasteland (scrub 
and woody areas) in Somosierra (99.85 ha), and from sloping wet pastures to scrubland (10.59 ha) or to wasteland (35.27 ha). In Bustarviejo, the most common changes were from sloping wet pastures to woodland with pastures (43.41 ha), and from dryland farming to sloping wet pastures (40.48 ha), grasslands (22.61 ha), woodland with pastures (25.09 ha), and valley bottom wet pastures (40.13 ha). Finally, in Rascafría, the most common changes were from valley bottom wet pastures to woodland with pastures ( $40.80 \mathrm{ha}$ ) or to urban land (49.03 ha), from dryland farming to grasslands (96.53 ha), sloping wet pastures (21.99 ha), valley bottom wet pastures (174.81 ha), woodland with pastures (98.26 ha) and to wasteland (scrub and woody areas) (291.29 ha), and from fruit and vegetable crops to urban land (12.35 ha).
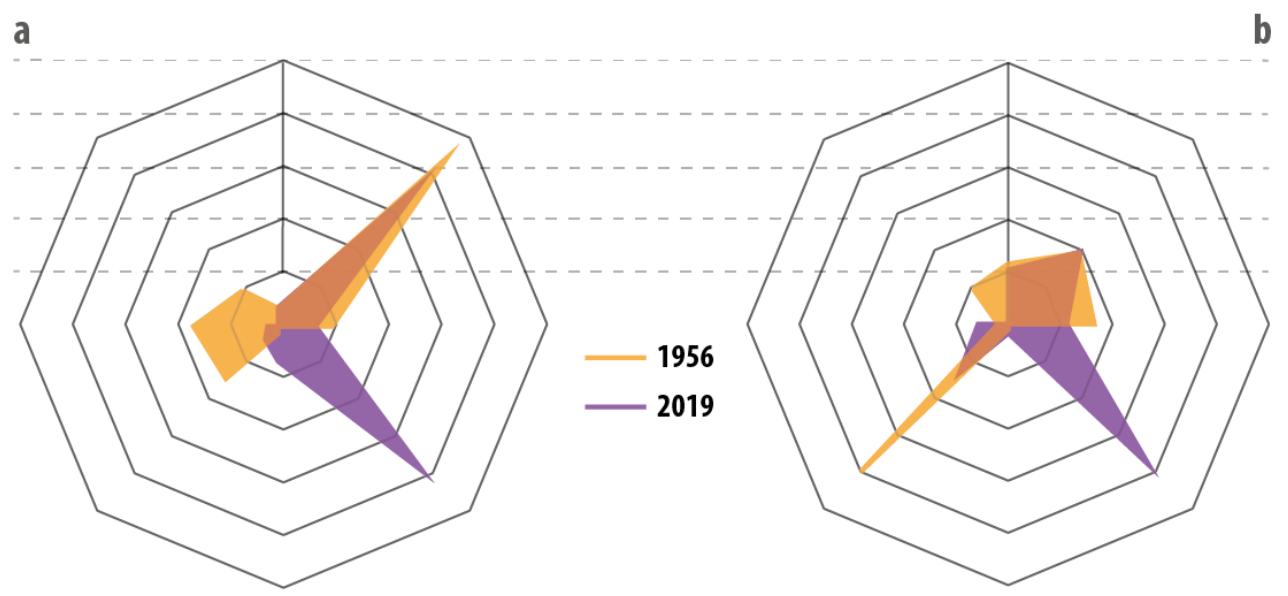

C
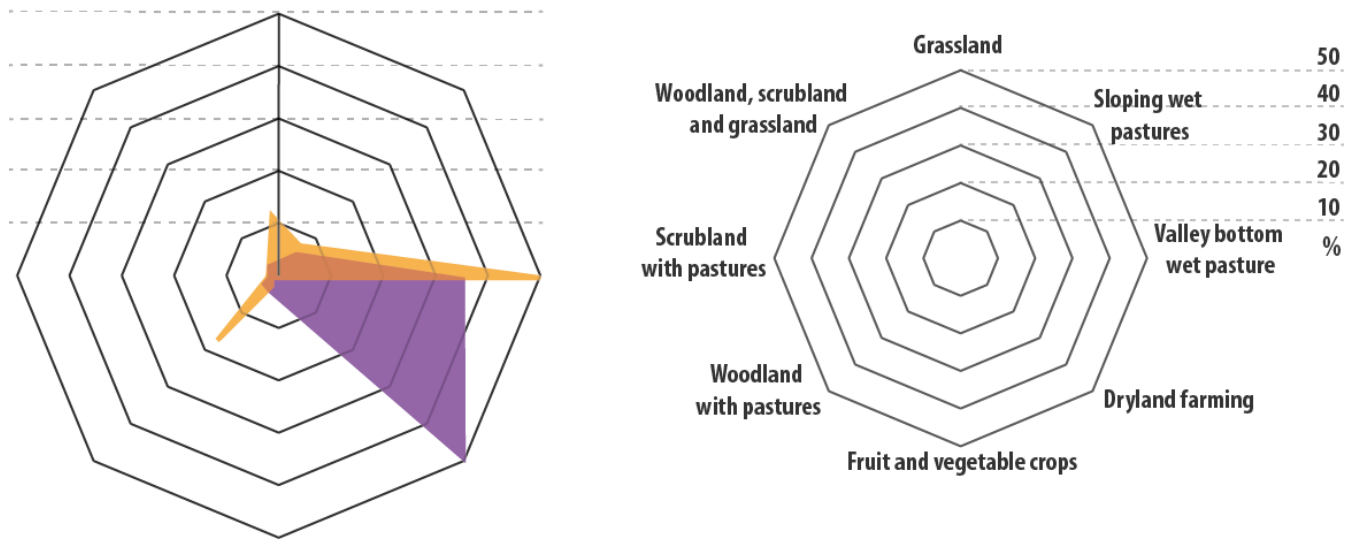

Figure 3. Relative land use of enclosed fields in Somosierra (a); Bustarviejo (b) and Rascafría (c) in 1956 and 2019. Own elaboration.

Table 3. Types of changes in land use and ha (reference codes in Table 2 and maximum values highlighted in bold).

\begin{tabular}{|c|c|c|c|c|c|c|c|c|c|c|c|c|}
\hline & & \multicolumn{11}{|c|}{2019} \\
\hline & & 1 & 2 & 3 & 4 & 5 & 6 & 7 & 8 & 9 & 10 & 11 \\
\hline \multirow{7}{*}{1956} & 1 & 38.63 & & & & 0.66 & 25.84 & 8.87 & 2.04 & 7.27 & & 12.06 \\
\hline & 2 & & 142.57 & & & & 69.68 & 11.33 & 22.02 & 1.21 & 4.54 & 60.37 \\
\hline & 3 & & & 420.48 & & 2.21 & 64.59 & 1.81 & 4.88 & 53.13 & 0.70 & 27.94 \\
\hline & 4 & 122.71 & 68.33 & 215.35 & & 15.10 & 124.81 & 16.43 & 21.28 & 13.13 & 4.51 & 407.47 \\
\hline & 5 & 1.58 & 8.19 & 20.75 & & 3.09 & 2.32 & 0.40 & 0.75 & 14.90 & 1.74 & 6.59 \\
\hline & 6 & 1.80 & 5.33 & 1.14 & & 0.15 & 46.32 & & 7.40 & 0.72 & & 26.52 \\
\hline & 7 & 0.39 & 3.83 & 1.13 & & & 7.31 & 2.62 & 3.18 & 1.09 & 0.10 & 16.26 \\
\hline
\end{tabular}


The tight valley where the enclosed fields of Somosierra are located determines that the main change is from fruit and vegetable crops, sloping wet pastures and dryland farming to sloping wet pastures and scrubland with pastures. In the granite alveoles with irregular filling of colluvium in Bustarviejo, dryland farming and sloping wet pastures shifted to mosaics of woodland with pastures, while the sloping wet pastures were maintained. Finally, the conditions in the apical zone of the tectonic basin where the enclosed fields of Rascafría are located were fundamental to explain the change from dryland farming and valley bottom wet pastures to valley bottom wet pastures and woodland with pastures.

An analysis of the changes detected in the enclosed fields is essential to understand how, in the middle of the 20th century, a multifunctional agro-landscape dominated in the area studied in which livestock (grasslands, sloping wet pastures, valley bottom wet pastures, woodland with pastures and scrubland with pastures: $1108.12 \mathrm{ha}$ ) and agricultural farming (dryland farming and fruit and vegetable crops: 1069.43 ha) were combined in a balanced manner. However, this system has now been radically simplified and the enclosed fields that are still active are organized into livestock farming (1496.09 ha) while the land for agricultural use hardly exceeds 20 ha in the entire study area (21.21 ha).

\subsection{Transformation Dynamics of Land Parcels Taking into Consideration Their Configuration and Density}

The information collected through the density and intensity of change in the enclosed parcels at the two dates made it possible to recognise and quantify the distributions and trends between these two dates. In Somosierra (195.3 ha), the high density of land parcels was associated with low-lying areas, irrigated or with concentrated run-off on slopes, occupying 59.2 ha in 1956 and 65.7 ha in 2019 (Figure 4), 30.3\% and 33.6\% of the total extension, respectively. Medium density land parcels occupy an area ranging between 76.4 ha (1956) and 85 ha (2019), representing 39.1\% and 43.5\% of the total extension, respectively. These areas were linked to sectors with pastures conditioned markedly by the seasonal rainfall. Finally, the low-density land parcels occupy 59.6 ha (1956) and 44.5 ha (2019), representing $30.5 \%$ and $22.7 \%$ of the total extension, respectively, and located on the most unproductive areas that include the high sloping wet pastures. The largest changes between the two dates occurred in the areas of medium density, over 105.4 ha (54\% of the total), and they were associated with the redistribution of fertile areas of the valley bottom or to the opening of enclosures on the lower slopes. The other two density intervals (low density and high density) that occupied areas of 47.6 ha (medium density) and 42.2 ha (low density).

In Arroyo del Valle (53.3 ha, Bustarviejo) two types of land parcels were differentiated based on their morphology (Figure 5): one strongly fragmented in the central area, and another more lax and poorly defined in the outermost sectors. High density land parcels dominated in a total of 22.7 ha (42.4\%) and 20.7 ha (38.9\%) in 1956 and 2019, respectively, and that were distributed in the central area of the alveoles and in small depressions. The medium density land parcels occupied the smallest area in 1956 (17.2 ha, 32.1\%) and 2019 (18.5 ha, 34.8\%), corresponding to sectors located on rocky areas or slopes with seasonal water supply. Finally, the lowest density land parcels occupied 13.5 ha (25.3\%) and 13.9 ha (26.2\%) in 1956 and 2019, respectively, extending over the more xeric marginal sectors. The highest rates of change were associated with the peripheral sectors of the alveoles, due to the general homogenization of the enclosures (13.9 ha, 26.3\%) and to the concentration around the more persistent wet areas. The sectors that have experienced the least changes (17 ha, 32\%) are those in the central area, where the land parcels maintained a similar division at both intervals, except in specific cases. Alternatively, those sectors that experimented with a medium rate of change were the land parcels in the immediate vicinity of the most functional alveoles and they had an extension of 22 ha $(41.5 \%)$. 

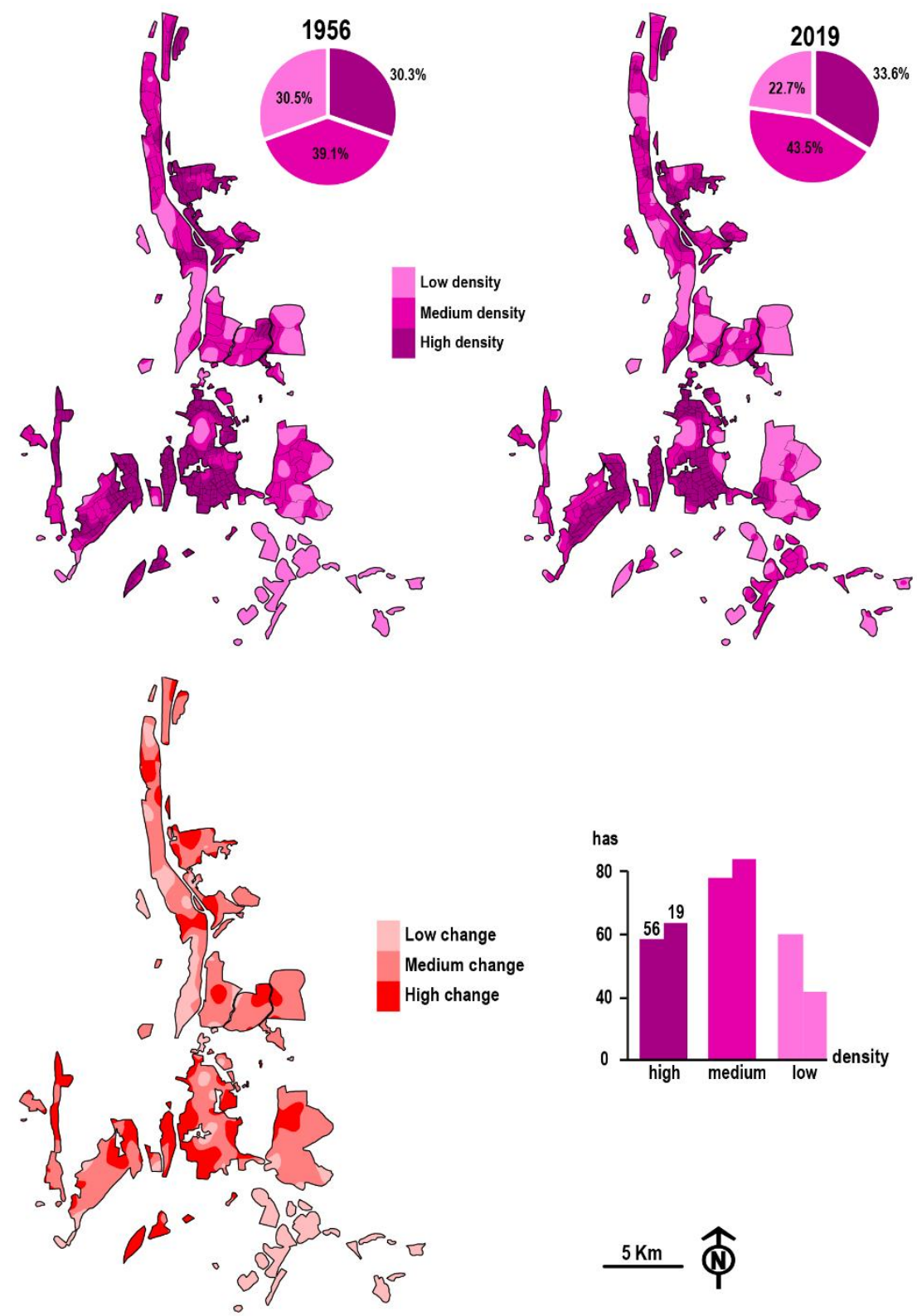

Figure 4. Density and changes in the Somosierra land parcels (1956-2019). Own elaboration.

The dimensions and size of the enclosed areas in Rascafría (941 ha) were two conditioning factors in the distribution and variety of its land parcels (Figure 6). Three specific parcel types could be differentiated: the first were highly fragmented and associated with the network of irrigation ditches on the Lozoya River; the second were associated with diffuse enclosures, established on the lower slopes; and finally, a residual type was located far from the water run-off from the slopes and they were used for dryland farming, which subsequently either underwent conversion into pasture or disappeared. The highest density land parcels reached extensions of 287.3 ha (30.5\%) in 1956 and 331 ha (35.1\%) in 2019, and they were mostly related to valley bottom mowing pastures or they were associated with the densest stretches of the transversal irrigation network. In this case, the network of land parcels was denser in 2019 relative to 1956 as a consequence of the proximity of the urban area and the processes of land parcel fragmentation. Land parcels with medium density values occupied 388.6 ha $(41.2 \%)$ and 370.4 ha $(39.3 \%)$ on dryland farming, grasslands or areas of difficult access. Lastly, low density land parcels covered 265 ha $(28.2 \%)$ and 240.3 ha $(25.2 \%)$, and they were associated with sloping wet pastures and old dryland farming areas that have maintained their physiognomy between the two dates analysed. 
Overall, rates of change are in the medium range and these occupied a surface of 737.7ha $(78.6 \%)$, indicative of the relative stability of the land parcels. By comparison, extreme changes occurred over much smaller surfaces. The areas with a change rate in the lowest range occupied a surface of 91 ha $(9.6 \%)$, with relative intense reparcelling in the areas associated with the existence of surface water. The areas with highest rates of change (109.7 ha, 11.6\%) were associated with dryland farming, marginal and poorly productive lands, and with intense fragmentation of the 1956 land parcels into long narrow strips.
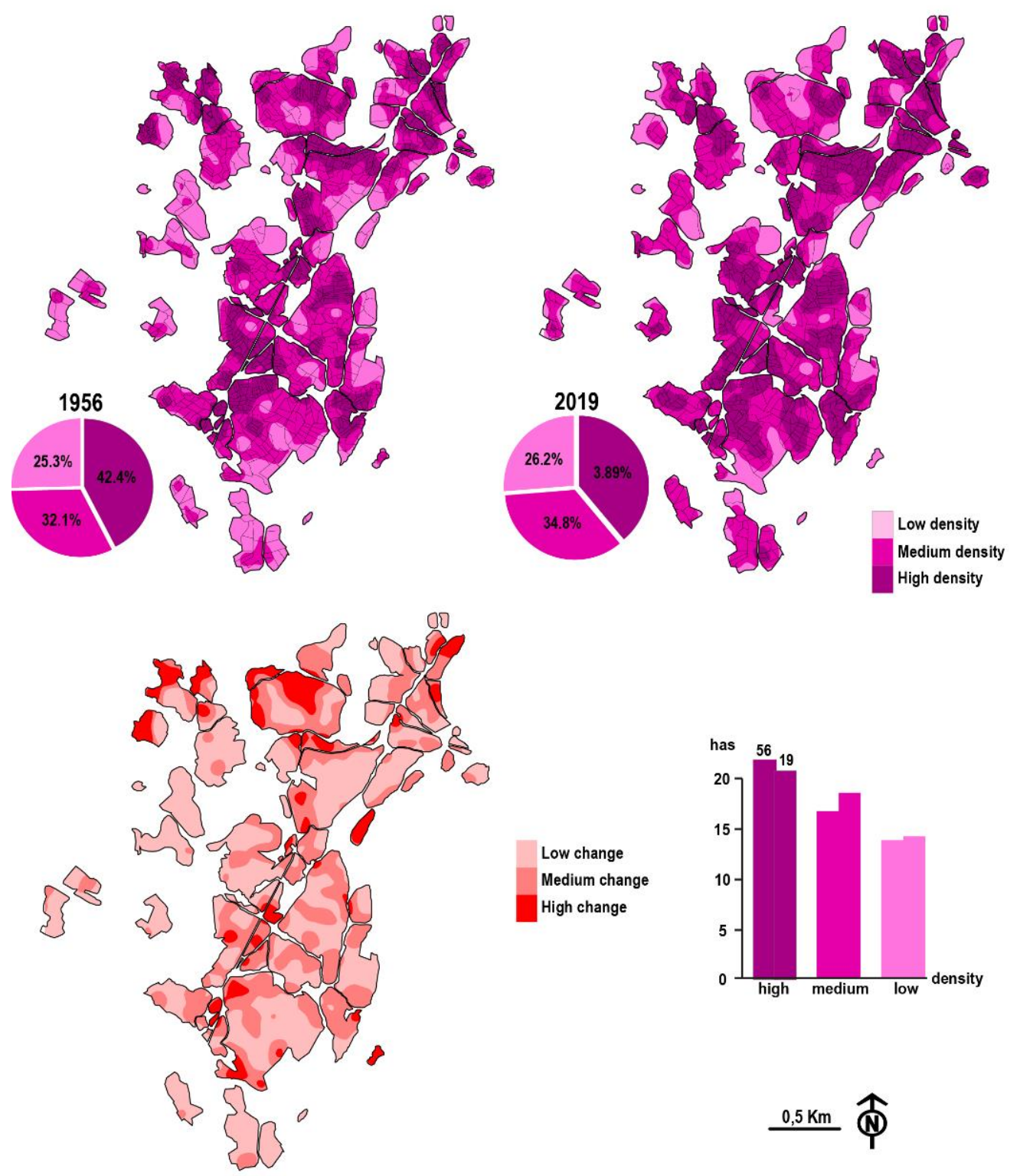

Figure 5. Density and changes in the Bustarviejo land parcels (1956-2019). Own elaboration.

From the field transects and the photointerpretation of the two sources of digital information used, two types of dynamics were identified that affect the boundaries and perimeters of the parcels of land (Figure 7). On the one hand, some of the parcels had been divided using wood and wire. 


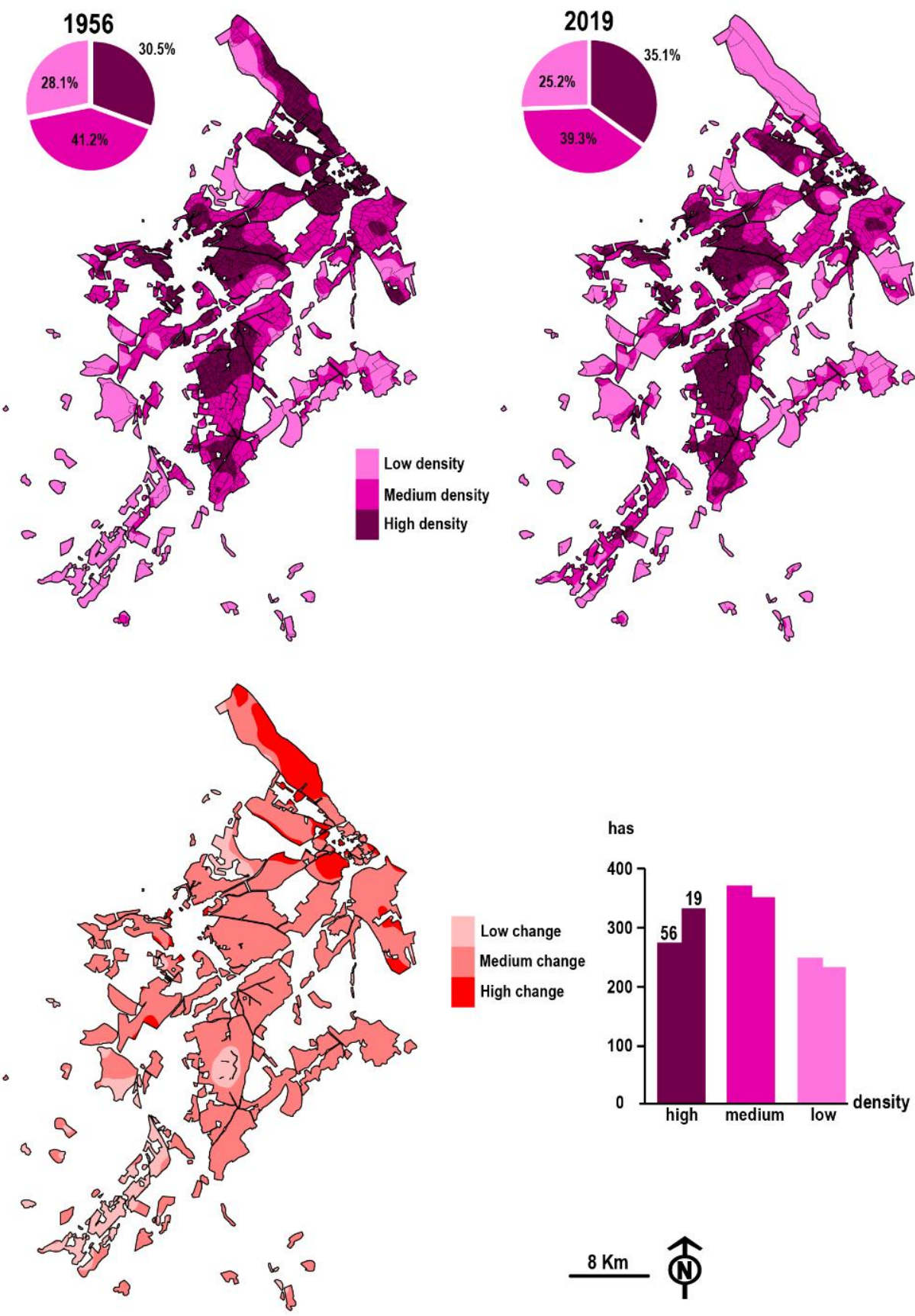

Figure 6. Density and changes in the Rascafría land parcels (1956-2019). Own elaboration.

From the point of view of the size of the parcels of land (Figure 8), the three study cases were characterized by having a very small mean parcel size, ranging between 0.1 and $1 \mathrm{ha}$. Regarding the changes to these land parcels, it was noteworthy that the distribution of the different types did not change substantially between 1956 and 2019, with very similar proportions maintained at the two dates. A detailed analysis revealed that two of the three nuclei experienced a reduction in the smaller land parcels, mainly in those of the $0-0.5$ ha size, a 3.7\% difference in Somosierra and 9.42\% in Bustarviejo) while Rascafría showed almost no variations between the two dates (maximum variation of $0.8 \%$ in the $1.5-2$ ha size type). A total of 1209 land parcels of the two types disappeared over the study period (321 in Somosierra, 380 in Bustarviejo and 508 in Rascafría). 


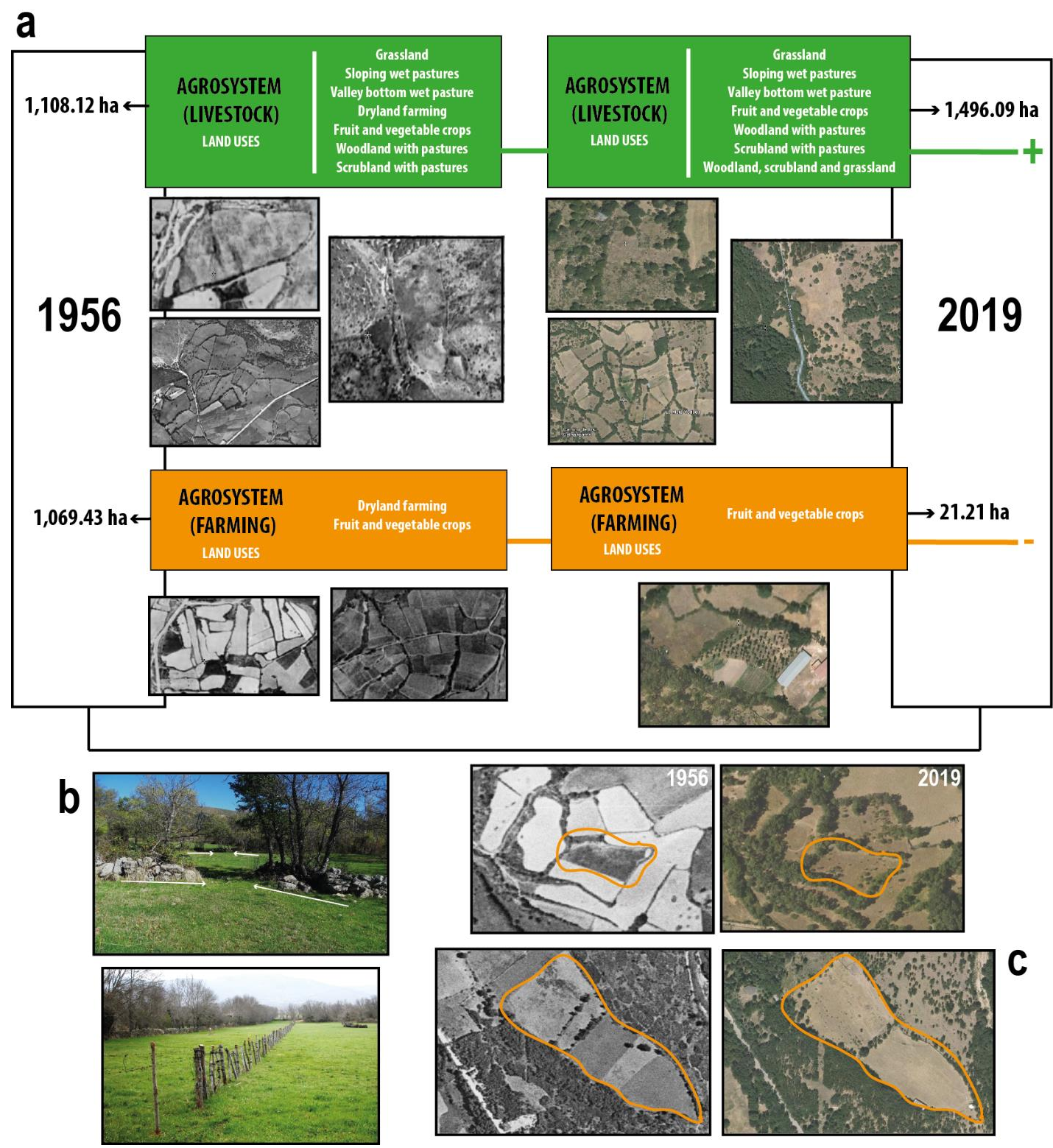

Figure 7. Agrosystem types and land uses (a) and examples of the transformation dynamics of land parcels: Bustarviejo, destruction of enclosures to facilitate the extensive passage of bovine livestock among parcels (b); Rascafría, division of land parcels due to inheritance partitions (c).
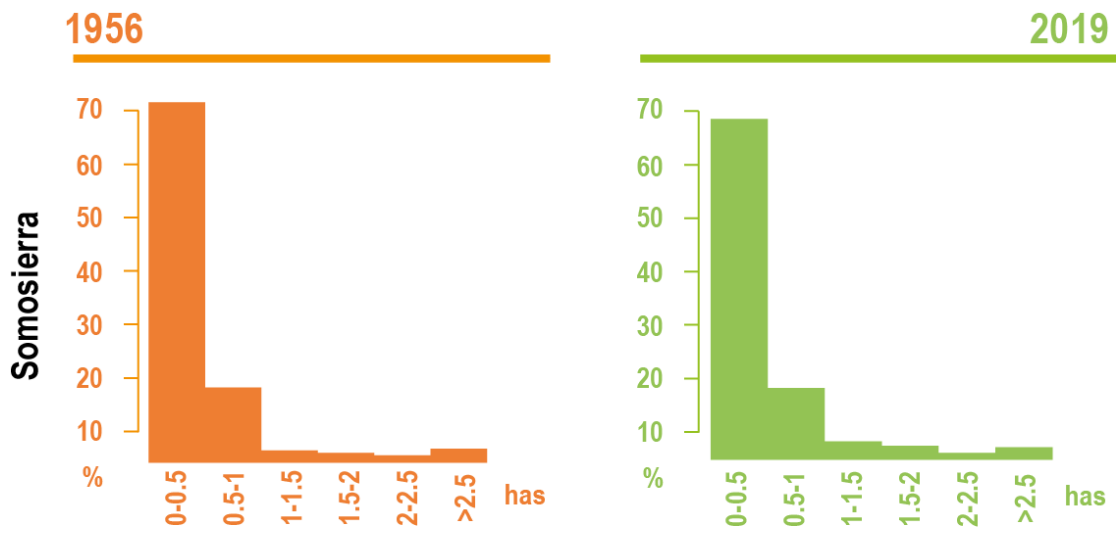

Figure 8. Cont. 

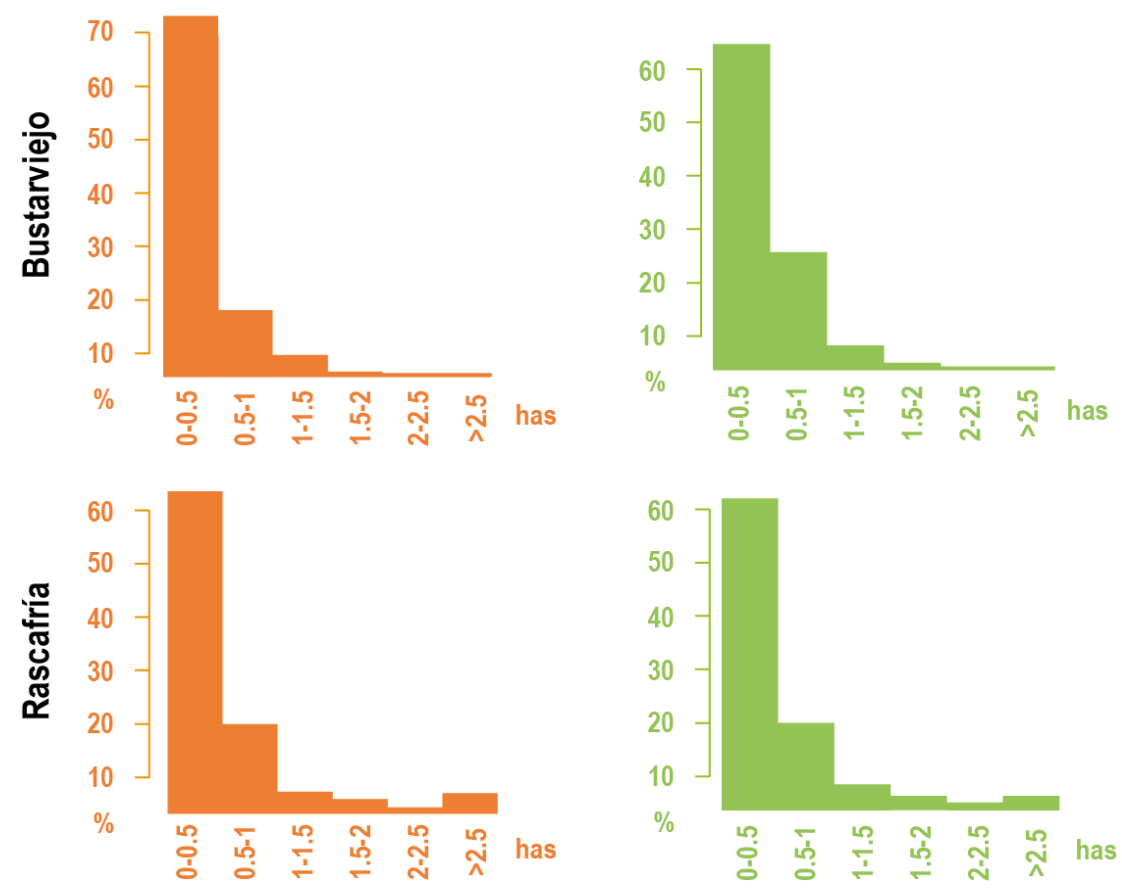

Figure 8. Relative surface area (ha) of enclosed fields in each municipality (1956-2019). Own elaboration.

\section{Discussion}

The changes in land use registered in the last 70 years enclosed fields in this area of the centre of the Spanish peninsula have been conditioned by different factors. It is important to bear in mind the role that surface moisture and slopes play in the types of agrosystems studied, as this is a fundamental issue to understand how the abandonment of enclosed fields occurs and their use transforms [21]. In addition, it is essential to note how quickly a system that had remained more or less stable for centuries [6,42-44] experiences such profound changes, jeopardizing its preservation. These modifications take place, on the one hand, in an economic context of the opening of markets, and on the other hand, in a geographical context of proximity to a metropolis, in this case Madrid (a maximum distance of $92 \mathrm{~km}$ to the Somosierra study site), a city that has multiplied its population from 1.6 million in the middle of the 20th century and to more than 6 million today. The disappearance of certain land uses, such as dryland farming, is widespread in a large part of the mountains and marginal European sectors [45-48]. In the study area, the transformation of agricultural spaces into livestock spaces has been very common in areas with relative edaphic humidity, while the driest areas have been widely abandoned [21,49]. Furthermore, some less common uses that have persisted in Mediterranean mountains over the decades may have a special significance in future multifunctional agri-food systems. This is the case of horticulture, agricultural production spaces that for decades have been destined to self-sufficiency, and that today acquire an interesting role in local marketing within the radius of influence of the large cities [50-52].

The agrosystem of Mediterranean enclosed fields has rarely been studied [53-56]. Its singularity resides in both a distribution confined to depressions in mountainous regions, in which the persistence of edaphic humidity is essential for its development and maintenance, and for the species and the uses of this land. In the cases studied here, a remarkable territorial parcelling (5412 units in three municipalities) complicates the management of this space, primarily in the current context of modern rural innovations. The shift experienced in large part of the interior mountains of the Spanish peninsula towards extensive livestock grazing, with little need to exploit hay meadows for winter food, converts it into an anachronistic landscape, with enormous difficulties for its maintenance [13-15,21,42,44]. However, the trend of European policies to favour agroforestry may be an opportunity for 
these systems, which, as shown above, have tended to expand the area covered by pastures with scrub woody areas (increasing from 89.38 ha in 1956 to 444 ha in 2019) [57-60].

The fragmentation of property and the change in density of the parcels are at the same time a reflection of heritage, landscape and biological wealth. However, this also represents a strong impediment to the innovation of productive activity [61], which plays a fundamental role in rural development [62]. The results of the present study allow us to propose that the characteristics of parcels can persist, although the changes experienced by this system are very profound [63]. These structures still maintain their density in the most fertile areas, and they may even undergo redensification, experiencing little changes on some occasions. However, small parcels suffer more abandonment and destruction, experimenting concentration processes that are also common in other parts of Spain and Europe [53-58,64]. This fact jeopardizes the preservation of this type of landscape, as such small parcels are those that underlie its unique character. Other morphologies of land parcels, such as those associated with dryland farming or dry pastures, have completely disappeared. As we have already described elsewhere [21,42,44,65], this landscape can be considered as small natural features (SNF) [66,67], that is spaces with an ecological importance disproportionate to their size.

The current dynamics of these spaces, without any kind of proposal or formula to protect and regulate their use by the different administrations [21,68], involves the destruction of the dry stone enclosure walls and the opening of spaces for pasture. This change to the landscape not only occurs in the study area but it has been common in recent decades in a large part of the mountainous sectors of the Mediterranean basin [69-72]. In these areas, traditional multifunctional systems (agriculture-forestry-livestock) have shifted towards other more simplified systems (livestock), which must be reconsidered in the European context in light of the new Community policy [73]. Furthermore, we must not forget that the system studied maintains productive livestock activity that should be approached as an opportunity to link landscape quality with food quality, particularly in peri-urban areas or, as is the present case, in areas relatively close to large cities $[68,74]$.

Agroforestry systems that include forestry and livestock uses in the same space have an outstanding value due to the social, ecological and economic benefits they provide, allowing sustainable development of the territories in which they are situated [75,76]. Furthermore, the European Forestry Strategy [77] explicitly mentions the importance of protecting and improving the practices developed in agroforestry systems as "they can help to confront the increasing challenges, including adaptation to climate change" [78]. These practices include the maintenance of forestry structures, the regeneration of native pastures, the rehabilitation of degraded pasture areas, the combination of agriculture and livestock, etc. [79].

\section{Conclusions}

The systems studied here face a very uncertain future, in which the loss of functionality due to abandonment of their use will drive a loss of rural heritage that is of great value. The changes in land use undergone in this agrosystem in recent decades jeopardize its preservation, with agricultural use almost completely disappearing and this space turning into a landscape mainly dedicated to livestock. Moreover, there is a trend towards modification of the internal underlying structure: the land parcels. A dynamic that if it continues, could put an end to the survival of this network of small units that compartmentalize a space, thereby generating the unique characteristics of Mediterranean environments with intense summer water stress. Further research will be necessary to explore the multifunctional and territorialized agri-food system characteristics of enclosed fields, the interest of food quality etiquettes, and the role they can play in conserving productive spaces and biodiversity under a system of exploitation capable of maintaining good environmental practices.

This work has been an approach to the diachronic identification, classification and quantification of land uses. Therefore, the changes in land use and their dynamics were considered taking into account their relationship with the morphology and density of land parcels. The 
authors believe that these results have allowed a better understanding and knowledge of the enclosed field environment within the continental Mediterranean mountains.

Author Contributions: F.A.Á., G.G.-M., N.L.-E., and P.M.H. devised the idea for this study, collected and analysed the data, and wrote the original manuscript; these authors assisted in the data collection and analysis, generated the figures included in the manuscripts, and reviewed the manuscript and the associated literature; J.A.B. assisted in the data collection. All authors have read and agreed to the published version of the manuscript.

Funding: This research was funded by Spanish Ministerio de Ciencia e Innovación PID2019105711RB-C61 /AEI/10.13039/501100011033. Project: “Multifunctional and territorialized agri-food systems in Spain. Conceptuation and governance. Case studies in Madrid and Castilla-La Mancha (SAMUTER MadCIM).

Institutional Review Board Statement: Not applicable.

Informed Consent Statement: Not applicable.

Data Availability Statement: Not applicable.

Conflicts of Interest: The authors have no conflict of interests to declare.

\section{References}

1. Mosquera-Losada, M.R.; McAdam, J.H.; Romero-Franco, R.; Santiago-Freijanes, J.J.; Rigueiro-Rodróguez, A. Definitions and components of agroforestry practices in Europe. In Agroforestry in Europe; Rigueiro-Rodríguez, A., McAdam, J., Mosquera-Losada, M.R., Eds.; Springer: Dordrecht, The Netherlands, 2009; pp. 3-19.

2. Plieninger, T.; Munoz-Rojas, J.; Buck, L.E.; Scherr, S.J. Agroforestry for sustainable landscape management. Sustain. Sci. 2020, 15, 1255-1266. [CrossRef]

3. Flinzberger, L.; Zinngrebe, Y.; Plieninger, T. Labelling in Mediterranean agroforestry landscapes: A Delphi study on relevant sustainability indicators. Sustain. Sci. 2020, 15, 1369-1382. [CrossRef]

4. Centeri, C.; Renes, H.; Roth, M.; Kruse, A.; Eiter, S.; Kapfer, J.; Slámová, M. Wooded grasslands as part of the European agricultural heritage. In Biocultural Diversity in Europe. Environmental History; Agnoletti, M., Emanueli, F., Eds.; Springer: Cham, Switzerland, 2016; Volume 5, pp. 75-103.

5. Rois-Díaz, M.; Mosquera-Losada, R.; Rigueiro-Rodríguez, A. Biodiversity Indicators on Silvopastoralism across Europe; EFI Technical Report 21; European Forest Institute: Joensuu, Finland, 2006; 66p.

6. Baudry, J.; Bunce, R.G.H.; Burel, F. Hedgerows: An international perspective on their origin, function and management. J. Environ. Manag. 2000, 60, 7-22. [CrossRef]

7. Van der Zanden, E.H.; Verburg, P.H.; Muncher, C.A. Modelling the spatial distribution of linear landscape elements in Europe. Ecol. Indic. 2013, 27, 125-136. [CrossRef]

8. Forman, R.T.T.; Baudry, J. Hedgerows and hedgerow networks in Landscape Ecology. Environ. Manag. 1984, 8, 499-510. [CrossRef]

9. Jose, S. Agroforestry for ecosystem services and environmental benefits: An overview. Agrofor. Syst. 2009, 76, 1-10. [CrossRef]

10. Maudsley, M.J. A review of the ecology and conservation of hedgerow invertebrates in Britain. J. Environ. Manag. 2000, 60, 65-76. [CrossRef]

11. Burel, F.; Baudry, J. Social, aesthetic and ecological aspects of hedgerows in rural landscapes as a framework for greenways. Landsc. Urban. Plan. 1995, 33, 327-340. [CrossRef]

12. Antrop, M. Why landscapes of the past are important for the future. Landsc. Urban. Plan. 2005, 70, 21-34. [CrossRef]

13. Sanz Herráiz, C.; López Estébanez, N.; Molina Holgado, P. Los campos cercados de las depresiones y piedemontes de las Sierras de Guadarrama y Somosierra (Sistema Central). In Proceedings of the Comunicaciones/III Congreso Español de Biogeografía, Universidad del País Vasco/Euskal Herriko Unibertsitatea, Urdaibai, Spain, 20-24 September 2006; pp. 419-426.

14. Sanz Herráiz, C.; Molina Holgado, P.; López Estébanez, N. Patrimonio cultural y medio ambiental en paisajes rurales. In XV Coloquio de Geografía Rural. Geografía y Desarrollo Rural. Territorio, Paisaje y Patrimonio Rural; Leco, F., Pérez, A., Mateos, A.B., Eds.; Universidad de Extremadura-Servicio de Publicaciones: Cáceres, Spain, 2010; pp. 585-597.

15. Gomez-Mediavilla, G.; López-Estébanez, N.; Allende Álvarez, F. Las fresnedas trasmochadas del piedemonte del Sistema Central en Madrid (España): Cambios y usos actuals. Estud. Rural. 2016, 6, 32-47.

16. Altieri, M.A. Biodiversity and Pest Management in Agroecosystems; Haworth Press: New York, NY, USA, 1994; 185p.

17. Harvey, C.A.; Villanueva, C.; Villacis, J.; Chacón, M.; Muñoz, D.; López, M.; Ibrahim, M.; Gomez, R.; Taylor, R.; Martínez, J.; et al. Contribución de las cercas vivas a la productividad e integridad ecológica de los paisajes agrícolas en América Central. Agroforestería Am. 2003, 10, 30-39.

18. Useche Rodriguez, D.C. Diseño de Redes Ecológicas de Conectividad Para la Conservación y Restauración del Paisaje en Nicaragua, Centroamérica. Ph.D. Thesis, Tropical Agricultural Research and Higher Education Center, Turrialba, Costa Rica, 2006. 
19. Berninger, F.; Salas, E. Biomass dynamics of Erythrina lanceolada as influenced by shoot-pruning intensity in Costa Rica. Agrofor. Syst. 2003, 57, 19-29.

20. Hinsley, S.A.; Bellamy, P.E. The influence of hedge structure, management and landscape context on the value of hedgerows to birds: A review. J. Environ. Manag. 2000, 60, 33-49. [CrossRef]

21. Allende Álvarez, F.; Gomez-Mediavilla, G.; López-Estébanez, N. Environmental, demographic, and policy drivers in the conservation of mediterranean hedgerow landscape (Spain). Land Use Policy. in press.

22. Riesco Chueca, P. Formas del parcelario: Su huella en la toponimia menor. Ería: Rev. Cuatrimest. De Geogr. 2014, 94, 183-205.

23. Fernández García, F. La representación gráfica de los paiajes rurales: Cuestiones de método. Ería Rev. Cuatrimest. Geogr. 2010, 83, 237-259.

24. Skaloš, J.; Engstová, B. Methodology for mapping non-forest wood elements using historic cadastral maps and aerial photographs as a basis for management. J. Environ. Manag. 2010, 91, 831-843. [CrossRef]

25. Š́t’astná, M.; Vaishar, A.; Vavrouchová, H.; Ševelová, M.; Kozlovská, S.; Doskočilová, V.; Lincová, H. Changes of a rural landscape in Czech areas of different types. Eur. Countrys. 2015, 7, 111-133. [CrossRef]

26. Lausch, A.; Blaschke, T.; Haasec, D.; Herzog, F.; Syrbee, R.; Tischendorff, L.; Walz, U. Understanding and quantifying landscape structure-A review on relevant process characteristics, data models and landscape metrics. Ecol. Model. $2015,295,31-41$. [CrossRef]

27. AEMET. Available online: https:/ / datosclima.es/Aemethistorico (accessed on 5 May 2020).

28. Spain MDE from USGS Shuttle Radar Topography. 2004. Available online: https://www.usgs.gov/centers/eros/science/usgseros-archive-digital-elevation-shuttle-radar-topography-mission-srtm-1-arc?qt-science_center_objects=0\#qt-science_center_ objects (accessed on 5 October 2020).

29. National Geographic Institute 1:200.000. Archive of Topographic Info. MTN200 Section. Available online: http:/ /www.ign.es/ csw-inspire/srv/eng/main.home (accessed on 5 October 2020).

30. Spanish National Geographic Institute (IGN). National Air Orthophotography Programme (PNOA). PNOA Section. Available online: http:/ / www.ign.es/csw-inspire/srv/eng/main.home (accessed on 20 October 2020).

31. Spanish National Geographic Institute (IGN). Archive of Historical Air Photography. Historical Orthophotography Section. Available online: http:/ / www.ign.es/csw-inspire/srv/eng/main.home (accessed on 20 October 2020).

32. Spanish Rustic Cadastre. Available online: http:/ / ovc.catastro.meh.es/Cartografia/WMS (accessed on 30 September 2020).

33. European Space Agency. Available online: https://scihub.copernicus.eu/dhus/\#/home (accessed on 10 June 2018 ).

34. Allende Álvarez, F.; Gomez-Mediavilla, G.; López-Estébanez, N. Classification of Mediterranean Hedgerows: A methodological approximation. Methods. in press.

35. Dayyani, L.; Pourtaheri, M.; Eftekhari, A.R.; Ahmadi, H. The identification and zoning of areas having rural det.eriorated textures in the Tehran province by using KDE and GIS. Hum. Ecol. Risk Assess. Int. J. 2019, 25, 475-504. [CrossRef]

36. Zahran, E.-S.M.M.; Shams, S.; Said, S.N.B.M. Validation of forest fire hotspot analysis in GIS using forest fire contributory factors. Syst. Rev. Pharm. 2020, 11, 249-255.

37. Silverman, B.W. Density Estimation for Statistics and Data Analysis; Chapman and Hall: New York, NY, USA, 1986.

38. Bonnier, A.; Finné, M.; Weiberg, E. Examining Land-Use through GIS-Based Kernel Density Estimation: A Re-Evaluation of Legacy Data from the Berbati-Limnes Survey. J. Field Archeol. 2019, 44, 70-83. [CrossRef]

39. Chen, X.; Ma, X.; Zhou, W. Kernel density regression. J. Stat. Plan. Inference 2020, 205, 318-325. [CrossRef]

40. Weglarczyk, S. Kernel density estimation and its application. In ITM Web of Conferences, 23, Proceedings of the XLVIII Seminar of Applied Mathematics, Boguszów-Gorce, Poland, 9-11 September 2018; Zielinski, W., Kuchar, L., Michalski, A., Kazmierczak, B., Eds.; EDP Sciences: Ulis, France, 2018.

41. ESRI Help Reference Guide. Available online: https://pro.arcgis.com/en/pro-app/sdk/api-reference/\#topic1.html (accessed on 6 June 2020).

42. Gomez-Mediavilla, G.; López Estébanez, N.; Allende Álvarez, F. Evolución del paisaje cultural de los campos cercados en las depresiones del piedemonte del Sistema Central (Madrid, España): Modificaciones en las relaciones del espacio urbano -rural. In Proceedings of the Actas del XXV Congreso de la Asociación de Geógrafos Españoles. Naturaleza, Territorio y Ciudad en un Mundo Global, Madrid, Spain, 25-27 October 2017; pp. 172-180.

43. Vandermotten, C.; Dézert, B. L'identité de l'Europe: Histoire et Géographie d'une Quête D'unité; Armand Colin: Paris, France, 2008.

44. Allende Álvarez, F.; Gomez-Mediavilla, G.; López-Estébanez, N.; Sobrino García, J. Podas y trasmochos en las Ordenanzas forestales del Sistema Central español y su impronta en el paisaje forestal actual. Cuad. Soc. Esp. Cienc. For. 2003, 38, 35-42.

45. Samanes, A.F. Campos cercados y abertales en la España atlántica. In Los Paisajes Rurales de España; Asociación de Geógrafos Españoles: Madrid, Spain, 1980; pp. 13-22.

46. Sanjuán, Y.; Arnáez, J.; Beguería, S.; Lana-Renault, N.; Lasanta, T.; Gómez-Villar, A.; García-Ruiz, J.M. Woody plant encroachment following grazing abandonment in the subalpine belt: A case study in northern Spain. Reg. Environ. Chang. 2018, 18, 1103-1115. [CrossRef]

47. Terres, J.M.; Scacchiafichi, L.N.; Wania, A.; Ambar, M.; Anguiano, E.; Buckwell, A.; Strijker, D. Farmland abandonment in Europe: Identification of drivers and indicators, and development of a composite indicator of risk. Land Use Policy 2015, 49, 20-34. [CrossRef] 
48. Poschlod, P.; Braun-Reichert, R. Small natural features with large ecological roles in ancient agricultural landscapes of Central Europe-history, value, status, and conservation. Biol. Conserv. 2017, 211, 60-68. [CrossRef]

49. Lasanta, T.; Arnáez, J.; Pascual, N.; Ruiz-Flaño, P.; Errea, M.P.; Lana-Renault, N. Space-time process and drivers of land abandonment in Europe. Catena 2017, 149, 810-823. [CrossRef]

50. Fuster Morell, M.; Espelt, R. A Framework to Assess the Sustainability of Platform Economy: The Case of Barcelona Ecosystem. Sustainability 2019, 11, 6450. [CrossRef]

51. Romero, J.; Melo, C. La Ordenación y Gestión de las Huertas Mediterráneas Españolas. El Tiempo de La(s) Política(S). In Paisaje, Cultura Territorial y Vivencia de La Geografía; Vera, M., Olcina, J.F., Hernández, J.Y., Eds.; Universidad de Alicante: Alicante, Spain, 2016 ; p. 362.

52. Noureddin, D.; Hmid, A.; Bilali, H.; Lipinska, I.; Berjan, S. Agri-Food Logistics in the Mediterranean Region: Challenges and Opportunities. In Proceedings of the International Forum on Agri-Food Logistics II, Poznań, Poland, 9-13 September 2014.

53. Bevan, A.; Conolly, J. Terraced fields and Mediterranean landscape structure: An analytical case study from Antikythera, Greece. Ecol. Model. 2011, 222, 1303-1314. [CrossRef]

54. Andlar, G.; Šrajer, F.; Trojanović, A. Discovering cultural landscape in Croatia: History and classification of Croatian Adriatic enclosed landscape. Ann. Ser. Hist. Sociol 2018, 28, 760-778.

55. Errea Abad, M.P.; Lasanta, T. Cambios en la cubierta vegetal de campos abandonados en función de los modelos de campos en Cameros Viejo (Sistema Ibérico). In Geoecología, Cambio Ambiental y Paisaje; Arnáez, J., González-Sampériz, P., Lasanta, T., Valero-Garcés, B.L., Eds.; Homenaje al Profesor José María García Ruiz, Instituto Pirenaico de Ecología (CSIC)—Universidad de La Rioja: Arnedo, Spain, 2014; pp. 383-393.

56. Peña-Angulo, D.; Khorchani, M.; Errea, P.; Lasanta, T.; Martínez-Arnáiz, M.; Nadal-Romero, E. Factors explaining the diversity of land cover in abandoned fields in a Mediterranean mountain area. Catena 2019, 181, 104064. [CrossRef]

57. Tatoni, T.; Roche, P. Comparison of old-field and forest revegetation dynamics in Provence. J. Veg. Sci. 1994, 5, 295-302. [CrossRef]

58. Tzanopoulos, J.; Mitchley, J.; Pantis, J.D. Vegetation dynamics in abandoned crop fields on a Mediterranean island: Development of succession model and estimation of disturbance thresholds. Agric. Ecosyst. Environ. 2007, 83, 83-94. [CrossRef]

59. Krčmářová, J.; Arnold, M. Traditional Agriculture as Cultural Heritage. Forgotten Agroforestry Practices Recorded in Textual Part of Nineteenth Century Tax Records. In Biocultural Diversity in Europe. Environmental History; Agnoletti, M., Emanueli, F., Eds.; Springer: Cham, Switzerland, 2016; Volume 5, pp. 211-231.

60. Rigueiro-Rodríguez, A.; Fernández-Núñez, E.; González-Hernández, P.; McAdam, J.H.; Mosquera-Losada, M.R. Agroforestry systems in Europe: Productive, ecological and social perspectives. In Agroforestry in Europe; Rigueiro-Rodríguez, A., McAdam, J., Mosquera-Losada, M.R., Eds.; Springer: Dordrecht, The Netherlands, 2009; pp. 43-65.

61. González, P.; Marey-Perez, M.; Álvarez-López, C. Evaluation of productive rural land patterns with joint regard to the size, shape and dispersion of plots. Agric. Syst. 2007, 92, 52-62. [CrossRef]

62. Schneider, J.; Ruda, A.; Venzlů, M. Development of the rural landscape: The Dačice Region case study, Czechia. Geogr. Tech. 2019, 14, 84-96. [CrossRef]

63. Ferrás, C.; Macía, X.; García, M.; Armas, F. El minifundio sostenible como un nuevo escenario para la economía gallega. Rev. Galega De Econ. 2004, 13, 1-25.

64. European Environment Agency. LANDSCAPE Fragmentation in Europe-Joint EEA-FOEN Report. 2011, p. 87. Available online: https:/ / www.eea.europa.eu/publications/landscape-fragmentation-in-europe (accessed on 27 April 2020).

65. López-Estébanez, N.; Allende Álvarez, F.; Gomez-Mediavilla, G.; Molina Holgado, P. Génesis y gestión de los campos cercados en el centro de la península Ibérica. Estud. Geogr.. in press.

66. Hunter, M.L., Jr.; Acuña, V.; Bauer, D.M.; Bell, K.P.; Calhoun, A.J.; Felipe-Lucia, M.R.; Lundquist, C.J. Conserving small natural features with large ecological roles: A synthetic overview. Biol. Conserv. 2017, 211, 88-95. [CrossRef]

67. Carlier, J.; Moran, J. Hedgerow typology and condition analysis to inform greenway design in rural landscapes. J. Environ. Manag. 2019, 247, 790-803. [CrossRef] [PubMed]

68. Gullino, P.; Devecchi, M.; Larcher, F. How can different stakeholders contribute to rural landscape planning policy? The case study of Pralormo municipality (Italy). J. Rural Stud. 2018, 57, 99-109. [CrossRef]

69. Barbera, G.; Cullotta, S. The Traditional Mediterranean Polycultural Landscape as Cultural Heritage: Its Origin and Historical Importance, Its Agro-Silvo-Pastoral Complexity and the Necessity for Its Identification and Inventory. In Biocultural Diversity in Europe. Environmental History; Agnoletti, M., Emanueli, F., Eds.; Springer: Cham, Switzerland, 2016; Volume 5, pp. 21-48.

70. Demková, K.; Hais, M.; Edwards-Jonášová, M. Cross-Border Comparison of Non-Forest Woody Vegetation in the White Carpathians (Central Europe) Over Last 65 Years. J. Landsc. Ecol. 2019, 12, 64-78. [CrossRef]

71. Pantera, A.; Papadopoulos, A.; Papanastasis, V.P. Valonia oak agroforestry systems in Greece: An overview. Agrofor. Syst. 2018, 92, 921-931. [CrossRef]

72. Paris, P.; Camilli, F.; Rosati, A.; Mantino, A.; Mezzalira, G.; Dalla Valle, C.; Franca, A.; Seddaiu, G.; Pisanelli, A.; Lauteri, M.; et al. What is the future for agroforestry in Italy? Agrofor. Syst. 2019, 93, 2243-2256. [CrossRef]

73. European Commission. The Post-2020 Common Agricultural Policy: Environmental Benefits and Simplification. 2020. Available online: https: / / ec.europa.eu/info/sites/info/files/food-farming-fisheries/key_policies/documents / cap-post-2020-environbenefits-simplification_en.pdf (accessed on 5 June 2020). 
74. Grando, S.; Brunori, G.; Pinto-Correia, T.; Sutherland, L.A. Small Farming and the Food System. In Innovation for Sustainability: Small Farmers Facing New Challenges in the Evolving Food Systems; Brunori, G., Grando, S., Eds.; Emerald Publishing Limited: Bingley, UK, 2020; Volume 25, pp. 9-18.

75. Den Herder, M.; Burgess, P.J.; Mosquera-Losada, M.R.; Herzog, F.; Hartel, T.; Upson, M.; Viholainen, I.; Rosati, A. Preliminary Stratification and Quantification of Agroforestry in Europe. Milestone Report 1.1 for EU FP7 Research Project: AGFORWARD 613520. 22 April 2015, p. 57. Available online: https://www.agforward.eu/index.php/es/preliminary-stratification-and-quantificationof-agroforestry-in-europe-copie-copie.html?file=files /agforward/documents/M1_Stratification\%20of\%20agroforestry.pdf (accessed on 24 April 2020).

76. Den Herder, M.; Moreno, G.; Mosquera-Losada, R.M.; Palma, J.H.N.; Sidiropoulou, A.; Santiago Freijanes, J.J.; Crous-Duran, J.; Paulo, J.A.; Tomé, M.; Pantera, A.; et al. Current extent and stratification of agroforestry in the European Union. Agric. Ecosyst. Environ. 2017, 241, 121-132. [CrossRef]

77. European Commission. Commission Communication to the European Parliament, the Council, the European Economic and Social Committee and the Committee of the Regions. 2013. Available online: https:/ / eur-lex.europa.eu/resource.html?uri=cellar: 21b27c38-21fb-11e3-8d1c-01aa75ed71a1.0022.01/DOC_1\&format=PDF (accessed on 15 May 2020).

78. Mosquera-Losada, M.R.; Santiago-Freijanes, J.J.; Rois-Díaz, M.; Moreno, G.; Den Herder, M.; Aldrey-Vázquez, J.A.; RigueiroRodríguez, A. Agroforestry in Europe: A land management policy tool to combat climate change. Land Use Policy 2018, 78, 603-613. [CrossRef]

79. Bhattacharyya, P.; Himanshu, P.; Sharmistha, P. Livestock and Aquaculture Management for Climate-Smart Agriculture. In Climate Smart Agriculture. Green Energy and Technology; Bhattacharyya, P., Himanshu, P., Sharmistha, P., Eds.; Springer: Singapore, 2020; pp. 113-127. 